\title{
The Performance of Probiotic with Addition of Purple Sweet Potato and Cassava Prebiotic on Immune Response of Tiger Prawn (Penaeus monodon Fab.)
}

\author{
Ummu Kaltsum ${ }^{1}$, Sriwulan $^{2}$, Hilal Anshary ${ }^{2}$ \\ ${ }^{1}$ Master Program, Postgraduate School, Hasanuddin University, Makassar, Indonesia. \\ ${ }^{2}$ Department of Fisheries, Faculty of Marine Sciences and Fisheries \\ Hasanuddin University, Makassar, Indonesia. \\ DOI: 10.29322/IJSRP.11.10.2021.p11855 \\ http://dx.doi.org/10.29322/IJSRP.11.10.2021.p11855
}

\begin{abstract}
This study aims to determine performance of Bacillus subtilis probiotic with addition of purple sweet potato and cassava prebiotics on immune response of tiger shrimp. The research is carried out at the Mini Hatchery of the Faculty of Marine and Fishery Sciences and the Laboratory of Fish Parasites and Diseases, Department of Fisheries, Faculty of Marine and Fishery Sciences, Hasanuddin University. The stages in this study consisted of: (1). Prebiotic preparation (of purple sweet potato and cassava), (2). Probitic preparation, and (3). Vibrio harveyi challange test. This research uses a completely randomized design with 4 treatments and 3 replications. The immune parameters measured includes total haemocyte count (Thc) Differentiation haemocyte count (Dhc) and phagocytic cell activities. Provision of probiotics and prebiotics froom the tubers (of cassava and purple sweet potato) could stimulate he celluler immune system of tiger shrimp after being challenged with Vibrio harveyi. The result showed that the best provision of probiotics with the addition of $20 \%$ cassava prebiotics was able to improve total haemocyte count ( $8.15 \times 10^{6}$ cells $\left./ \mathrm{ml}\right)$, phagocytic activity $73 \%$ and hemocyte differentiation is almost the same pattern in each treatment.
\end{abstract}

Keywords: Bacillus subtilis, thc, dhc, phagocytic activity

\section{INTRODUCTION}

Tiger prawns ( Penaeus monodon) is one of the cultivated organisms that has grown very rapidly as a big industry and has become an important source of animal protein favoured by consumers. However, the production of tiger prawn traded in the market is not sustainable due to the deterioration in environmental quality and disease attacks. These two problems particulary occurrence of various diseases are the main obstacles in tiger shrimp cultivation activities nowadays. One of the shrimp diseases agent that frequently found attack prawn is disease caused by Vibrio harveyi bacteria . V. harveyi is a common opportunistic pathogen found in shrimp farming environments, which may cause disease problem when entering the aquaculture system.

An approach that can be done in the prevention of bacterial diseases is by increasing non-specific immune responses through the provision of probiotics and prebiotics which are known to have immunomodulatory effect, relatively easy to obtain and more environmentally friendly. Probiotics are living organisms that have a beneficial effects on the healt of the host by improving the balance of bacteria in the gut. Many research on probiotics have been carried out to increase the production of aquaculture as a dietary supplement ( Nayak, 2010 ). In addition the probiotic bacteria are competitors against pathogens and are able improve the immune system ( El- Bouhy e $t$ al. 2013). Several bacteria from different genus are widely used as aquaculture probiotics, including Bacillus sp. ( Boonthai, Vuthiphandchai, and Nimrat 2011; Hoseinifar et al. 2018). Bacillus bacteria is known to inhibit the growth of Vibrio harveyi bacteria that attacks larvae in hatchery and causing up to $100 \%$ mortality of shrimp larvae in hatchery. One of 
bacteria that is commonly use as probiotic is Bacillus subtilis which has the ability to inhibit Vibrio harveyi bacteria (Zokaei, et al . 2009).

In order to maintain the presence of probiotic bacteria in the digestive tract, prebiotics are needed as a substrate that can stimulate the growth of probiotics (Widanarni et al., 2012). One of the potential substances that may function as prebiotics are sweet potato and cassava. Materials that may be used as prebiotics are generally carbohydrates (poly- and oligosaccharides) that cannot be digested in the host's digestive tract. The high content of undigested carbohydrates such as dietary fibre in processed products of tubers such as sweet potato and cassava allows it to be developed as food source of prebiotics. Prebiotics are generally derived frm oligosaccharide compounds, such as fructooligosaccharides (FOS), mannanoligosaccharides (MOS), and galactooligosaccharides (GOS) which cannot be digested by the host, but induce normal microflora to grow in the digestive tract which is beneficial for probiotics (Delgado et., al 2011). Previous studies have shown that prebiotics can improve the composition of the microflora in the gut, inhibit the growth of pathogens, and enhance the immune response in shrimp ( Aktas et al. 2014; Zhang et al. 2012 ).

The use of probiotics and prebiotics in feed can increase immunity, lower intestinal $\mathrm{pH}$, and help improve digestive tract performance by stimulating pancreatic enzyme secretion by suppressing the growth of pathogenic bacteria, increasing the growth of beneficial microflora, and ensuring digestive enzymes function optimally (Bozkurt et al., 2009). ). Therefore, this study aims to examine the performance of probiotic bacteria with the addition of prebiotics from different types of tubers; purple sweet potato and cassava, on the immune response of tiger shrimp to Vibrio harveyi bacterial infection.

\section{Research Method}

This research was conducted in September - December 2020. Experiment was conducted at the Mini Hatchery, Faculty of Marine and Fisheries Sciences, Hasanuddin University. Process of preparing experimental feed was carried out at the Laboratory of the brackish Aquaculture Research Center in Maros. Preparations for probiotic, challenge tests, immune responses measurements were carried out at the Fish Disease and Parasite Laboratory, Department of Fisheries, Faculty of Marine and Fisheries Sciences, Hasanuddin University.

\section{Materials and method}

The containers used for rearing tiger prawns were 12 pieces of aquariums with have size of 50x45x45cm. The aquaria were placed indoors, and each aquarium was equipped with aeration to maintain stability of dissolved oxygen and temperature.

The tested animals used in this study were tiger shrimp obtained from farmers in the Maros area, South Sulawesi with a weight ranging from 7-10 grams with a density of 10 shrimp/liter.

The experimental design used in this study was a completely randomized design (CRD). The treatments tested in this study were:
A : Control (without probiotics and prebiotics)
B : Probiotics without the addition of prebiotics
C : Probiotics with the addition of $20 \%$ sweet potato prebiotics
D : Probiotics with the addition of $20 \%$ cassava prebiotics

\section{Prebiotic preparation}


The prebiotics derived from tubers (of cassava and purple sweet potato) were cleaned to remove adhering dirt, and all were peeled off and then washed with clean water to remove the dirt. Then, they were thinly sliced for easy processing, then dried and grinded to fine powders.

The finely grinded feed ingredients are then added with fish oil, a mixture of minerals and vitamins, then stirred until well mixed. After evenly mixed, then warm water was added to the mixture of raw feed to form a dough or paste. The dough based on the formulation was then printed with a pellet printing machine. Then the feed was air dried for 1-2 days at room temperature, then proximate analysis was conducted for the feed before use.

\section{Probiotic preparation}

The probiotic used in this study was Bacillus subtilis which was obtained from the collection of the Microbiology Laboratory of the Faculty of Pharmacy, Unhas. Then the bacteria were re-culture on Trypticase Soy Agar (TSA) media and incubated for 24 hours at $30^{\circ} \mathrm{C}$ to serve as stock. All microbiology processes were carried out aseptically and carried out in a laminar chamber to prevent contamination from other microorganisms.

\section{Vibrio harveyi challenge test}

Application provision of probiotic and prebiotic treatment was carried out for 14 days of rearing, then on the day 15 tiger prawns were challenged with Vibrio harveyi at a concentration of $10^{7} \mathrm{CFU} / \mathrm{ml}$ in the ventral sinus in the second abdominal segment (Huang et al. 2013).

\section{Total Haemocyte Count (the)}

THC calculation method used referred to the method of Maftuch et al., (2013). Haemolymph was taken as much as $0.1 \mathrm{~mL}$ from the base of the first swimming leg using a $1 \mathrm{~mL}$ syringe which contained $0.3 \mathrm{~mL}$ of $3.8 \%$ Na-citrate anticoagulant. The mixture was homogenized by shaking the hand to form a figure eight. The hemolymph was then dripped onto the haemocytometer and covered with a cover glass. Furthermore, the hemocytic cells were observed using a microscope with a magnification of 100 times. The number of cells was calculated using the formula (Nurhaedah, 2017);

$$
\mathrm{THC}(\text { cells } / \mathrm{mL})=\text { Cell average } \mathrm{x} 25 \times 10^{4}
$$

\section{Differentiation Haemocyte Count (dhc)}

The observation of haemocytic differentiation (DHC) was carried out by referring to the method of Martin and Graves (1985). Haemolymph was droipped on a glass object and made a smear preparation, then air dried. After drying, the haemolymph preparation (specimens) was fixed with absolute methanol for 5-10 minutes and then air dried. This preparation (specimens) was immersed in 10\% Giemsa dye solution for 15-20 minutes. After that, the preparation was washed in tap water with running water and then allowed to dry. The haemolymph was examined under a microscope with a magnification of 100 times, and the cell types were identified. The number of haemocytes was counted up to 100 cells, and the percentage of each type was determined. The number of haemocytes cell types that were counted was 100 cells, then the percentage of each cell type was calculated by the formula (Nurhaedah, 2017):

$$
\text { Dhc }=\frac{\text { number of each type of haemocyte cell }}{\text { total haemocytes }} \times 100 \%
$$

\section{Phagocytic activity}

Shrimp haemolimph was taken as much as 0.1 using a $1 \mathrm{~mL}$ syringe filled with $0.1 \mathrm{~mL}$ anticoagulant. Then $50 \mu$ of blood was put into a microplate, and $50 \mu$ of Staphylococcus aureus suspension was added in PBS ( $\left.10^{7} \mathrm{cel} / \mathrm{ml}\right)$. It was homogenized using This publication is licensed under Creative Commons Attribution CC BY. 
a vortex and incubated at room temperature for 20 minutes. A total of $5 \mu 1$ was dropped on a glass object and made smear preparation and dried in air. Then it was fixed with methanol for 5-10 minutes, dried, and soaked in Giemsa staining solution for 15-20 minutes. it was then washed with running water and dried with a tissue paper. The number of cells showing the process of phagocytosis from 100 observed phagocytic cells was the counted. The phagocytic index was calculated by the formula:

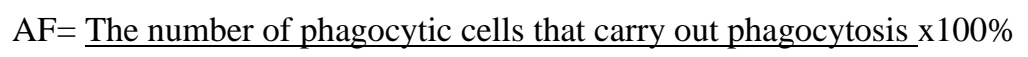

Haemocyte cell count

\section{RESULTS AND DISCUSSION}

\section{Result}

\section{Total Haemocyte Count}

Table 1. Total haemocytic count during the study after treatment and after the Vibrio harveyi challenge test.

\begin{tabular}{ccc}
\hline Treatment & THC & $\left(\right.$ X $10^{6}$ cell $\left./ \mathrm{ml}\right)$ \\
\cline { 2 - 3 } & After treatment & After challenge test \\
\hline A (control) & $6 \pm 0,36^{\mathrm{a}}$ & $5.4 \pm 0,1^{\mathrm{a}}$ \\
B & $6.8 \pm 0,22^{\mathrm{a}}$ & $7.05 \pm 0,22^{\mathrm{b}}$ \\
C & $7.15 \pm 0,07^{\mathrm{a}}$ & $8.1 \pm 0,13^{\mathrm{b}}$ \\
D & $7.4 \pm 0,22^{\mathrm{a}}$ & $8.15 \pm 0,15^{\mathrm{b}}$ \\
\hline
\end{tabular}

Different codes show significant differences $(\mathrm{P}<0.05)$

The results of the measurement of total haemocytes after treatment with probiotics with the addition of cassava have a high concentration compared to other treatments. After being injected with Vibrio harveyi, the THC value of tiger prawns in all treatments increased whereas for controls it decreased. Based on the results of the analysis of variance, it shows that the administration of probiotics with the addition of prebiotics has a significant effect ( $\mathrm{p}<0.05)$ on THC after the challenge test. Tuckey's further test results shows that the total haemocytes of tiger prawns in control are significantly different from the treatment with probiotics without prebiotics and probiotics with the addition of cassava and purple sweet potatoes.

\section{Differential Haemocyte Count}

Table 2. Differential Haemocyte Count during the study after treatment

\begin{tabular}{cccc}
\hline Treatment & Granular & Average $(\%) \pm$ SD & Hialin \\
& $34.67 \pm 0.57$ & $30.33 \pm 1.15$ & $35 \pm 1$ \\
A & $35 \pm 2$ & $29.33 \pm 1.15$ & $35.67 \pm 1.15$ \\
C & $31.33 \pm 3.12$ & $32 \pm 3$ & $36.67 \pm 5.77$ \\
D & $35.67 \pm 2.51$ & $27.33 \pm 1.5$ & $37 \pm 4.35$
\end{tabular}

The results shows that there is an increase in the number of granular and hyaline cells in each treatment. The highest number of granular and hyaline cells is found in the probiotic treatment with the addition of cassava prebiotics. Meanwhile, semigranular cells decreases in probiotic treatment with the addition of purple sweet potato and cassava prebiotics. The results of analysis of variance show that the treatment given to tiger prawns has no significant effect $(p>0.05)$ on the differentiation of haemocyte count. 


\section{Phagocytic Activity}

Table 3. Phagocytic activity of tiger prawns after treatment and after the Vibrio harveyi challenge test.

\begin{tabular}{ccc}
\hline Treatment & \multicolumn{2}{c}{ Fagositosis Activities (\%) \pm SD } \\
\cline { 2 - 3 } & After Treatment & After Challenge test \\
\hline A & $44 \pm 16,13^{\mathrm{a}}$ & $40 \pm 14,19^{\mathrm{a}}$ \\
B & $50 \pm 19,12^{\mathrm{a}}$ & $50 \pm 12,89^{\mathrm{ab}}$ \\
C & $47 \pm 1,99^{\mathrm{a}}$ & $61 \pm 0,13,2^{\mathrm{ab}}$ \\
D & $53 \pm 7,45^{\mathrm{a}}$ & $73 \pm 7,18^{\mathrm{b}}$ \\
\hline
\end{tabular}

Different codes show significant differences $(\mathrm{P}<0.05)$

Based on the results of the analysis of variance, it shows that the administration of probiotics with the addition of prebiotics has no significant effect ( $p>0.05$ ) on phagocytic activity, but after the challenge test, the treatment has a significant effect on phagocytic activity. The results of the Tuckey test show that the administration of probiotics with the addition of cassava prebiotics is significantly different from the control, while there is no significant difference between the treatment of probiotics with the addition of sweet potato prebiotics and probiotics without the addition of prebiotics.

\section{Discussion}

The immune system has a function as a guardian of the body's health from attacks by pathogens or harmful foreign objects that enter the body. Throughout the day the tiger prawns identify good bacteria and pathogens that enter their bodies. During the process, antibody cells will work together in the bloodstream to stop the spread of viruses and other pathogenic bacteria. Haemocytes, as the first immune system in shrimp and invertebrate groups, have an important role in removing foreign particles in haemolymph through the process of phagocytosis, encapsulation and nodular aggregation.

The results of the observation of total haemocyte values at the end of treatment and after the Vibrio harveyi challenge test show that probiotics with the addition of cassava and sweet potato prebiotics have the highest haemocyte values, followed by probiotics without prebiotics and the lowest in the control treatment. This increase is a response from the immune system in shrimp. This is because the body's defense system in shrimp that plays a role is the body's defense mechanism by haemocytes, where the spread and increase in the total number of haemocytes is assumed to be a form of cellular immune response in the shrimp body (Van de Braak 2002). The results of observations increase in each treatment, and the highest is obtained in the treatment of probiotic administration with the addition of $20 \%$ cassava prebiotic. High total haemocytes indicate that the chance of forming phagocytic cells in controlling the attack of pathogenic organisms remains high and can improve the immune system (Nurhaedah, 2017). In shrimp, the increase in hemocyte cells in the shrimp body plays an important role in inhibiting or destroying pathogens that enter the shrimp body. The increase in THC is also caused by lectin molecules which are part of the shrimp's immune defense which functions to recognize foreign objects (non-self recognition) that enter the shrimp's body (Rodriguez \& Le Moullac, 2000).

This increase in hemocyte value indicates that the chances of forming phagocytic cells in controlling the attack of pathogenic organisms remain high and can improve the tiger shrimp's immune system. Changes in the number of haemocytes is one indicator of health status in shrimp. In addition, haemocytes are also involved in the synthesis and release of important molecules, such as -2-macroglobulin $(\alpha 2 \mathrm{M})$, agglutinins and antibacterial peptides as a defense reaction of the crustacean body (Rodriguez and Moullac, 2000). Provision of good bacteria is added with prebiotics as a component that can prevent pathogens and is able to stimulate haemocyte cells. In addition, Bacillus subtilis which produces bacteriocin compounds can prevent the growth of pathogenic bacteria (Scetzer, 2006). The antibacterial ability released by these haemocytic cells in collaboration with Bacillus compounds is able to suppress pathogens in the tiger shrimp body. 
The results of DHC observations shows that the highest percentage of hyaline cells and granular cells is found in the treatment with probiotics with the addition of $20 \%$ cassava prebiotic followed by probiotic treatment with the addition of purple sweet potato prebiotics, probiotics without prebiotics, and the lowest was in the control. On the other hand, the percentage of semigranular cells decreases from each treatment. The increase in hyaline and granular cells before the challenge causes the phagocytic ability to also increase, so that when the shrimp are challenge tested with Vibrio harveyi, they can survive the pathogen. Hyaline cells are non-specific defenses that are generally able to protect against disease attacks by phagocytosing or engulfing pathogenic cells (Johansson et al., 2000). While granular cells are cells with a lower ratio of the cell nucleus than the cytoplasm. These cells function in storing and releasing the proPO system as well as cytotoxic together with semigranulocyte cells and play a role in phagocytosis, which correlates with their capacity and intracellular killing. (Johansson et al., 2000).

The highest phagocytic activity is obtained in the treatment of probiotic Bacillus subtilis with the addition of $20 \%$ cassava prebiotic, followed by treatment with probiotics with the addition of purple sweet potato prebiotic, then probiotics without prebiotics and controls. The administration of microbial components in the body can activate the body's defense response cellularly. This can be observed through phagocytic activity which is the main activity in the shrimp body's defense process against foreign body infections. Although the differentiation of haemocyte count has no significant effect, the three haemocyte cells have an effect on phagocytic activity, where the resul of hyaline cells and granular cells in this study increases which becomes an indicator of phagocytic activity. Phagocytic activity is closely related to the increase in the number of hyaline cells because the cells that carry out the phagocytosis process are hyaline cells and few are semi-granular (Ermantianingrum et al., 2003). Similar to the increase in total haemocyte count, the bacteriocin compounds in Bacillus subtilis bacteria are able to carry out the lysis process during a pathogen attack so that the haemocyte cells will also carry out the degranulation, cytotoxicity, and lysis processes of the material. Thus, the number of circulating haemocytes in the haemocytes will seem decreased. The result of the degranulation process is the release of peroxectin which will trigger the emergence of phagocytosis (Effendy et al., 2004).

\section{Conclusion}

the provision of probiotic Bacillus subtilis with the addition of $20 \%$ cassava prebiotic can increase the immune response of tiger prawns in the form of THC, DHC, and phagocytic activity.

\section{References}

Boonthai, T., V. Vuthiphandchai, and S. Nimrat. 2011. Probiotic bacteria effects on growth and bacterial composition of black tiger shrimp (Penaeus monodon). Aquaculture Nutrition 17:634-44.

Delgado G T C, Tamashiro W M S C, Junior M R M, Moreno Y M F and Pastore G M 2011 The putative effect of prebiotics as immunomodulatory agent Food Res. Inter. 44 3173-3167.

El-Bouhy ZM, El-Nobi GA, Hassanin ME, El- Hady MA. 2013. Effects of dietary application of two antagonistic gut-isolated Bacillus species on the immune response of Oreochromis niloticus to Aeromonas hydrophila infection. Zagazig Veterinary Journal, 41(2): 31-39.

Effendy, S. Alexander, R dan T. Akbar. 2004. Peningkatan hemosit benur udang windu (Penaeus monodon Fab) pasca perendaman ekstrak ragi roti (Saccharmoyces cerevisiae) pada konsentrasi yang berbeda. Jurnal Sains dan Teknologi, 14(2):46-53.

Ermantianingrum, A.A., Sari, R., dan S.B. Prayitno. 2013. Potensi Chlorella sp. Sebagai Imunostimulan untuk Pencegahan Penyakit Bercak Putih (White Spot Syndrome Virus) pada Udang Windu (Penaeus monodon). Journal of Aquaculture Management and Technology. Vol.1(1),206-221. 
Huang, H., X. Liu, J. Xiang and P. Wang. 2013. Selection of Vibrio harveyi-Resistent Litopenaeus vannamei Via Three-round Challenge Selection With Pathogenic Strain of Vibrio harveyi. Fish and Shelfish Immunology.35:328-333.

Johansson M.W., Keyser P., Sritunyalucksana K. and Söderhäll K. 2000.Crustacean haemocytes and haematopoiesis.Aquaculture, 191:45-52.

Maftuch, Prasetio E, Sudianto A, Rozik M, Nurdiyani R, Sanusi E, Nursyam H, Fariedah F, Marsoedi, Murachman. 2013. Improvement of innate immune responses and defense activity in tiger shrimp Penaeus monodon Fab. by intramuscular administration of the outer membrane protein Vibrio alginolyticus. Springer Plus 2: 432-440

Martin, G.G. and Graves, L.B. 91985. Structur and Classification of Shrimp Haemocytes. J. Morfology. 185:339-348.

Nayak S. 2010. Probiotics and immunity: a fish perspective. Fish Shellfish Immunology, 29(1): 2-14.

Nurhaedah. 2017. Penggunaan RNA Untai Ganda (dsRNA) Protein Permukaan 19 (VP19) White Spot Syndrome Virus (WSSV) untuk Pengendalian Infeksi Virus WSSV pada Udang Vaname (Penaeus vannamei). Program, Studi Ilmu Perikanan, Universitas Hasanuddin.

Rodriguez J., and Le Moullac G. 2000. State of the art of immunological tools and health control of Penaeid Shrimp.Aquaculture, 191: 109-119.

Tanbiyaskur. 2011. Efektivitas pemberian probiotik, prebiotik, dan sinbiotik melalui pakan untuk pengendalian infeksi Sterptococcus agalactiae pada ikan nila Oreochromis niloticus [tesis]. Bogor (ID): Institut Pertanian Bogor.

Van de Braak, K. 2002. Haemocytic defence in black tiger shrimp (Penaeus monodon), Disertasion, van Wareningen Universiteit, Germany, 159p.

Widanarni, Widagdo P, Wahjuningrum D. 2012. Aplikasiprobiotik, prebiotik, dan sinbiotik melalui pakan pada udang vaname Litopenaeus vannamei yang diinfeksi Vibrio harveyi. Jurnal Akuakultur Indonesia 11: 54-63.

Zhang, J., Y. Liu, L. Tian, H. Yang, G. Liang, and D. Xu. 2012. Effects of dietary mannan oligosaccharide on growth performance, gut morphology and stress tolerance of juvenile Pacific white shrimp, Litopenaeus vannamei. Fish Shellfish Immunology 33:1027-32.

Zokaei, H.F., Saad, C.R.B, Daud, H.M., Sharr Azni Harmin, S.A., \& Shakibazadeh, S. 2009. Effect of Bacillus subtilis on the growth and survival rate of shrimp (Litopenaeus vannamei). African Journal of Biotecnoogy, 8(14). 